\title{
Tingkatkan Hasil Belajar Materi Globalisasi Siswa Kelas VI SD dengan Media Video Pembelajaran
}

\section{Kadek Disky Ari Budi Utama ${ }^{1}$, Ndara Tanggu Renda ${ }^{2}$, Gede Wira Bayu ${ }^{3}$}

\author{
1,2,3 Program Studi Pendidikan Guru Sekolah Dasar, Universitas Pendidikan Ganesha, Singaraja, Indonesia
}

\section{ART ICLE INF O}

Article history:

Received June 19, 2021

Revised June 20, 2021

Accepted July 30, 2021

Available online December 25, 2021

Kata Kunci:

Video Pembelajaran, Globalisas

Keywords:

Learning Video, Globalization

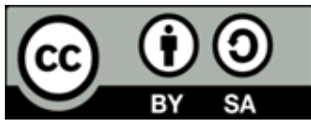

This is an open access article under the CC BY-SA license.

Copyright $(2021$ by Author. Published by Universitas Pendidikan Ganesha.

\begin{abstract}
A B S T R A K
Pada masa ini kegiatan belajar mengajar tidak dapat dilakukan secara tatap muka, khususnya pada daerah yang terdampak Covid-19 sehingga wajib dilakukan dengan pembelajaran jarak jauh. Kurangnya media pembelajaran yang menarik dan menyenangkan bagi siswa dalam mengikuti pembelajaran PPKn berdampak pada rendahnya prestasi belajar siswa. Dibutuhkan media pembelajaran inovatif yang dapat meningkatkan mutu pembelajaran dan mewujudkan proses belajar yang lebih bermakna bagi siswa. Tujuan dari penelitian ini adalah menciptakan video pembelajaran untuk meningkatkan hasil belajar materi globalisasi siswa kelas VI SD. Penelitian ini merupakan penelitian dan pengembangan (Research and Development) dengan model. Subjek yang terlibat dalam penelitian ini, yaitu dua orang ahli materi, dua orang ahli madia, empat orang guru PPKn, dan 23 orang. Teknik pengumpulan data dalam penelitian ini menggunakan kuisioner dengan instrument yang terdiri atas kuisioner meliputi karakteristik, tingkat validitas, kepraktisan, dan keefektifan media video pembelajaran globalisasi pada mata pelajaran PPKn kelas VI yang diperoleh dengan menggunakan teknik penyebaran kuisioner kepada subjek penelitian. Hasil data kualitatif yang diperoleh dianalisis secara deskriptif. Tingkat validitas media video pembelajaran globalisasi pada mata pelajaran PPKn kelas VI termasuk dalam kategori sangat valid, dilihat nilai kevalian pada ahli materi sebesar 1,00 dan nilai kevalidan pada ahli media sebesar 1,00. Tingkat kepraktisan media video pembelajaran globalisasi pada mata pelajaran PPKn kelas VI termasuk dalam kategori sangat praktis, dilihat dari nilai kepraktisan dengan yaitu sebesar 89. Maka video pembelajaran layak dan valid digunakan untuk meningkatkan hasil belajar siswa.
\end{abstract}

\begin{abstract}
A B S T RACT
At this time, teaching and learning activities cannot be carried out face-to-face, especially in areas affected by Covid-19, so distance learning must be carried out. The lack of interesting and fun learning media for students in participating in Civics learning has an impact on students' low learning achievement. Innovative learning media are needed that can improve the quality of learning and create a more meaningful learning process for students. The purpose of this research is to create a learning video to improve the learning outcomes of the sixth graders of elementary school globalization. This research is a research and development (Research and Development) with a model. The subjects involved in this study were two material experts, two media experts, four PPKn teachers, and 23 people. The data collection technique in this study used a questionnaire with an instrument consisting of a questionnaire covering the characteristics, level of validity, practicality, and effectiveness of globalization learning video media in Civics Class VI subjects obtained by using a questionnaire distribution technique to research subjects. The results of the qualitative data obtained were analyzed descriptively. The level of validity of the globalization learning video media on Civics Class VI subjects is included in the very valid category, judging by the validity value of the material expert at 1.00 and the validity value of the media expert being 1.00. The level of practicality of globalization learning video media in Civics Class VI subjects is included in the very practical category, judging from the practicality value of 89 . Then the appropriate and valid learning videos are used to improve student learning outcomes.
\end{abstract}




\section{PENDAHULUAN}

Pendidikan pancasila dan kewarganegaraan (PPKn) merupakan salah satu mata pelajaran yang dibelajarkan pada jenjang SD. Meskipun proses pembelajaran berlangsung berdasarkan tema-tema sesuai kurikulum 2013, namun PPKn tetap menjadi salah satu muatan pembelajaran yang dibelajarkan secara terintegrasi dengan muatan pembelajaran lainnya. Tujuan pembelajaran muatan PPKn adalah membekali siswa dengan kemampuan berpikir kritis, kreatif, rasional, berkarakter dan bertanggungjawab (Aprilia et al., 2018; Murni, 2018). Kemampuan ini diperlukan untuk mempersiapakan siswa nantinya menjadi warga negara yang mampu menanggapi segala isu yang berhubungan dengan kewarganegaraan dengan bijak, menjadi warga negara yang memahami dan bisa melaksanakan hak dan kewajiban sebagai warga negara secara seimbang (Fatmawati \& Rizal, 2020; Hasanah et al., 2020; Mediatati \& Suryaningsih, 2017). Hal ini sejalan dengan tuntutan pembelajaran abad 21 yang berfokus pada pengembangan kemampuan berpikir tingkat tinggi siswa (Ayala, 2021; Boso et al., 2021; Lavi et al., 2021; Susilo \& Ramdiati, 2019). (Ayala, 2021). Dalam upaya memenuhi tuntutan tersebut, diperlukan proses pembelajaran yang lebih inovatif sehingga suasana pembelajaran menjadi lebih menarik yang membuat siswa mau terlibat secara aktif dalam proses pembelajaran. Proses pembelajaran yang demikian adalah ciri pembelajaran yang berkualitas dan diharapkan terjadi di kelas (Khaulani et al., 2019; Pt. Ratih Siswinarti, 2019). Upaya yang dapat dilakukan guru untuk menciptakan pembelajaran yang berkualitas adalah melalui penerapan strategi, model, metode dan media pembelajaran yang tepat (Hastuti et al., 2019; Miswandi, 2018; Suandewi et al., 2017).

Namun faktanya di lapangan proses pembelajaran khususnya muatan PPKn dapat dikatakan belum berlangsung optimal. Hasil wawancara yang dilaksanakan di kelas VI SD Negeri 1 Nusasari ditemukan beberapa permasalahan dalam pembelajaran muatan PPKn, yaitu: ketersediaan media pembelajaran yang masih sangat terbatas, hal ini berimbas pada jarangnya penggunaan media dalam pembelajaran; keterbatasaan kemampuan guru dalam membuat media yang sesuai dengan karakteristik materi dan siswa; buku siswa menjadi satu-satunya sumber belajar siswa. Selain itu, beberapa penelitian juga menyebutkan beberapa penyebab belum optimalnya proses pembelajaran muatan PPKn adalah guru belum menerapkan strategi, model, dan metode pembelajaran sesuai dengan materi yang dibelajarkan. Lebih lanjut, penggunaan media pembelajaran yang masih sangat kurang membuat rendahnya minat belajar siswa yang ditunjukan dari rendahnya keterlibatan siswa dalam mengikuti pembelajaran (Asmedy, 2021; Diana Sari et al., 2019; Farida Hasan Rahmaibu, 2017; Murni, 2018; Ramadhani, 2017). Keadaan ini diperburuk seiring diberlakukannya proses pembelajaran daring secara penuh yang terkesan tiba-tiba akibat adanya wabah Covid-19 yang melanda hampir seluruh negara di dunia. Beberapa penelitian menyebutkan proses pembelajaran daring masih berlangsung kurang efektif dan hal ini menjadi tantangan baru bagi guru dan siswa (Hong et al., 2021; Jr. et al., 2021; Mishra et al., 2020; Scherer et al., 2021). Apabila permasalahan tersebut tidak segera diatasi akan berdapak pada rendahnya hasil belajar siswa khususnya pada muatan PPKn dan dalam dampak yang lebih luas dapat berakibat pada rendahnya kualitas sumber daya manusia Indonesia.

Berpijak dari permasalahan di atas, salah satu upaya yang bisa dilakukan untuk menanganinya adalah dengan mengembangkan media yang mampu menunjang proses pembelajaran kearah pemenuhan tujuan pembelajaran PPKn secara optimal. Media yang sesuai dikembangkan adalah video pembelajaran. Fokus materi pada muatan PPKn yang diambil adalah globalisasi. Penggunaan media video dalam pembelajaran membuat proses pembelajaran menjadi lebih bermakna dan memberikan kesan menarik karena siswa belajar melalui kegiatan mendengar dan melihat (Ananda, 2017; Kwangmuang et al., 2021; Layona et al., 2017; Ridha et al., 2021). Kelebihan media video adalah dapat memusatkan perhatian dan memudahkan siswa dalam belajar karena siswa mendapat gambaran nyata tentang materi yang dipelajari dalam bentuk gambar dan suara (Naharir et al., 2019; Siswinarti, 2019; Sri Kartika Dewi et al., 2019). Hasil penelitian tentang pemanfaatan media video dalam pembelajaran baik yang dipadukan dengan model pembelajaran atau tanpa model pembelajaran telah memberikan dampak positif terhadap peningkatan hasil belajar PPKn siswa SD (Aditya et al., 2019; Gusnawan \& Renda, 2017; Purbasari et al., 2016). Pengembangan video pembelajaran sejatinya sudah dilakuan pada penelitian-penelitian sebelumnya dan hasilnya media ini dinyatakan valid dan layak untuk dikembangkan (Hikmah \& Ahmadi, 2019; Kurniyawati \& Nugraheni, 2021). Namun, hal yang membedakan media video yang dikembangkan pada penelitian ini dengan penelitian sebelumnya, yaitu: materi yang diambil adalah materi globalisai; video diawali dengan judul yang menarik dan jelas; berisikan salah satu lagu wajib Indonesia; berisikan himbauan untuk tetap mematuhi protokol kesehatan; dilengkapi dengan ilustrasi gambar dan video yang menarik serta musik background yang ceria; dan dilengkapi dengan simpulan materi yang dibahas serta latihan soal. Tujuan penelitian ini adalah untuk menilai media video yang dikembangkan dari beberapa aspek, seperti: aspek karakeristik media, validitas, kepraktisan, dan keefektifan sehingga media video yang dibuat layak untuk dikembangkan. Harapan dari pengembangan media ini adalah membantu 
memudahkan guru dan siswa dalam mempelajari materi globalisasi dan menciptakan suasana pembelajaran yang lebih menarik, sehingga akhirnya dapat meningkatkan hasil belajar siswa.

\section{METODE}

Jenis penelitian yang digunakan dalam penelitian ini merupakan penelitian pengembangan (research and development) yang berorientasi kepada sebuah produk. Produk yang dikembangkan adalah media video pembelajaran globalisasi pada mata pelajaran PPKn kelas VI SD Negeri 1 Nusasari. Model penelitian pengembangan yang digunakan yaitu model pengembangan ADDIE (Analyze, Design, Development, Implementation, Evaluation). Metode pengumpulan data yang digunakan adalah metode angket/kuisioner untuk mengumpulkan data hasil review dari ahli uji, uji coba guru dan siswa. Subjek yang terlibat dalam penelitian ini, yaitu dua orang dosen ahli materi, dua orang dosen ahli madia, empat orang guru PPKn, dan 23 orang siswa dari SD Negeri 1 Nusasari. Teknik pengumpulan data dalam penelitian ini menggunakan kuisioner dengan instrument yang terdiri atas kuisioner validitas dan uji keefektifan. Teknik analisis data yang digunakan pada penelitian ini yaitu analisis deskriptif kualitatif dan analisis deskriptif kuantitatif. Tahap pertama yaitu analisis (Analyze) yang dilakukan yaitu menganalisis kebutuhan terhadap media yang dikembangkan dan analisis terhadap karakteristik siswa. Kegiatan ini dilakukan agar mengetahui permasalahan-permasalahan yang terjadi dalam kegiatan pembelajaran PPKn. Pada tahap analisis (Analyze) meliputi beberapa tahapan yang dilaksanakan, yaitu mengamati masalah yang ada, analisis kurikulum, analisis kebutuhan, serta analisis media.

Tahap kedua dalam pengembangan model ADDIE adalah tahap perancangan (Design) tahapan ini fokus pada materi yang akan dikemas kedalam media, serta alur penyampain materi dalam media video pembelajaran. Perancangan ini dimulai dari penentuan topik materi yang cocok untuk dikembangkan dalam media video pembelajaran, kemudian membuat rancangan media dari bagian pembuka, materi topik yang dipilih berupa video animasi, latihan soal, dan penutup. Setelah proses rancangan selesai kemudian dilanjutkan dengan memohon bimbingan pada dosen pembimbing untuk mendapatkan masukan dan saran terkait desain yang sudah dirancang. Tahap ketiga dalam pengembangan model ADDIE adalah tahap pengembangan. Pada tahap ini, rancangan yang disusun pada tahap desain kemudian dikembangkan menjadi media video pembelajaran. Kegiatan pada tahap ini terdiri dari melakukan proses penyusunan materi/bahan ajar, penyusunan animasi yang menarik untuk siswa, pembuatan materi yang sesuai dengan video pembelajaran yang sudah akan dibuat, dan penyusunan soalsoal berupa kuis atau lembar kerja peserta didik sebagai instrumen penilaian. Semua penyusunan tersebut diimplementasikan ke dalam media video pembelajaran yang dikembangkan dan disesuaikan dengan materi pembelajaran yang ada pada silabus. Kemudian dilanjutkan dengan tahap pengujian media dengan memberikan lembar penilaian kepada para ahli yang terdiri dari dosen ahli media, ahli materi dan guru. Data yang diperoleh dari hasil uji ahli kemudian dianalisis agar diketahui validitas media video pembelajaran yang telah selesai dibuat kemudian diperbaiki jika ada saran dan masukan.

Pada tahap implementasi (Implementation) dilakukan jika media telah dinyatakan valid serta layak untuk digunakan dalam pembelajaran. Implementasi media dilaksanakan untuk mengetahui respon siswa dan guru terhadap media yang dikembangkan. Pada tahap implementasi ini diujicobakan kepada beberapa guru yang ada di SD Negeri 1 Nusasari. Pada tahap evaluasi, yaitu tahap ini menilai kualitas dari produk yang sudah dikembangkan. Pada tahap ini media yang dikembangkan dievaluasi, juga berdasarkan saran validator maupun mahasiswa dalam tahap implementasi, karena mungkin saja masih terdapat beberapa kekurangan dalam media yang dikembangkan. Teknik pengumpulan data yang digunakan dalam penelitian pengembangan ini adalah kuisioner. Adapun kisi-kisi instrument yang digunakan dapat dilihat pada Tabel 1, 2, dan 3.

Tabel 1. Kisi-kisi Lembar Validasi Media

\begin{tabular}{|c|c|c|c|c|}
\hline No & Aspek & Indikator & Jumlah Butir & Nomor Butir \\
\hline \multirow{3}{*}{1} & \multirow{3}{*}{ Visual } & $\begin{array}{l}\text { Kesesuaian media yang ditampilkan dengan materi } \\
\text { yang diajarkan. }\end{array}$ & 2 & 1,2 \\
\hline & & $\begin{array}{l}\text { Tampilan media mendukung pembelajaran sesuai } \\
\text { perkembanmgan siswa. }\end{array}$ & 3 & $3,4,5$ \\
\hline & & Kemenarikan gambar dan jenis huruf. & 2 & 6,7 \\
\hline \multirow{3}{*}{2} & \multirow{3}{*}{$\begin{array}{c}\text { Suara dan } \\
\text { Teks }\end{array}$} & Kejelasan penggunaan efek suara/musik. & 3 & $8,9,10$ \\
\hline & & Teks dapat dibaca dengan baik. & 2 & 11,12 \\
\hline & & Tata letak atau penempatan teks disusun dengan baik. & 3 & $13,14,15$ \\
\hline 3 & Penyajian & $\begin{array}{l}\text { Kesesuaian ukuran huruf yang digunakan dengan } \\
\text { ukuran media. }\end{array}$ & 3 & $16,17,18$ \\
\hline
\end{tabular}




\begin{tabular}{|c|c|c|c|c|}
\hline No & Aspek & Indikator & Jumlah Butir & Nomor Butir \\
\hline & & Kesesuaian tata letak gambar dan tulisan. & 3 & $19,20,21$ \\
\hline & & Ketepatan pemilihan warna. & 3 & $22,23,24$ \\
\hline & & Pokok bahasan tiap bagian jelas. & 4 & $25,26,27$ \\
\hline & & Jumlah & & 27 \\
\hline
\end{tabular}

Tabel 2. Kisi-kisi Instrumen Validasi Ahli Materi

\begin{tabular}{|c|c|c|c|c|}
\hline No & Aspek & Indikator & \multicolumn{2}{|c|}{ Jumlah Butir Nomor Butir } \\
\hline \multirow{4}{*}{1} & \multirow{4}{*}{ Materi } & $\begin{array}{l}\text { Kompetensi dasar dan indikator sesuai dengan } \\
\text { materi dan disampaikan dengan jelas }\end{array}$ & 2 & 1,2 \\
\hline & & $\begin{array}{l}\text { Tujuan pembelajaran sesuai dengan materi dan } \\
\text { disampaikan dalam media dengan jelas }\end{array}$ & 2 & 3,4 \\
\hline & & $\begin{array}{l}\text { Tujuan pembelajaran sesuai dengan kompetensi } \\
\text { dasar. }\end{array}$ & 2 & 5,6 \\
\hline & & $\begin{array}{l}\text { Tingkat kesulitan materi sesuai dengan } \\
\text { perkembangan kognitif siswa }\end{array}$ & 2 & 7,8 \\
\hline & & Penyampaian materi dapat menarik minat belajar. & 2 & 9,10 \\
\hline 2 & Penyajian & Materi disajikan secara runtut sesuai alur & 1 & 11 \\
\hline & & Kejelasan dalam penyajian materi & 2 & 12,13 \\
\hline & & $\begin{array}{l}\text { Pemilihan kalimat sesuai dengan materi yang } \\
\text { disampaikan. }\end{array}$ & 1 & 14 \\
\hline 3 & Kebahasaan & Penggunaan bahasa yang baik dan benar. & 1 & 15 \\
\hline & & $\begin{array}{l}\text { Kalimat yang digunakan mudah dipahami dan } \\
\text { dimengerti }\end{array}$ & 1 & 16 \\
\hline & & Jumlah & & 16 \\
\hline
\end{tabular}

Tabel 3. Kisi-kisi Instrumen Validasi Praktisi

\begin{tabular}{|c|c|c|c|c|}
\hline No & Aspek & Indikator & Jumlah Butir & Nomor Butir \\
\hline \multirow{4}{*}{1} & \multirow{4}{*}{ Materi } & $\begin{array}{l}\text { Kompetensi dasar dan indikator sesuai dengan } \\
\text { materi dan disampaikan dengan jelas }\end{array}$ & 2 & 1,2 \\
\hline & & $\begin{array}{l}\text { Tujuan pembelajaran sesuai dengan materi dan } \\
\text { disampaikan dalam media dengan jelas }\end{array}$ & 2 & 3,4 \\
\hline & & $\begin{array}{l}\text { Tujuan pembelajaran sesuai dengan kompetensi } \\
\text { dasar. }\end{array}$ & 2 & 5,6 \\
\hline & & $\begin{array}{l}\text { Tingkat kesulitan materi sesuai dengan } \\
\text { perkembangan kognitif siswa }\end{array}$ & 2 & 7,8 \\
\hline \multirow{3}{*}{2} & \multirow{3}{*}{ Penyajian } & $\begin{array}{l}\text { Penyampaian materi dapat menarik minat } \\
\text { belajar. }\end{array}$ & 2 & 9,10 \\
\hline & & Materi disajikan secara runtut sesuai alur & 1 & 11 \\
\hline & & Kejelasan dalam penyajian materi & 2 & 12,13 \\
\hline \multirow{3}{*}{3} & \multirow{3}{*}{ Kebahasaan } & $\begin{array}{l}\text { Pemilihan kalimat sesuai dengan materi yang } \\
\text { disampaikan. }\end{array}$ & 1 & 14 \\
\hline & & Penggunaan bahasa yang baik dan benar. & 1 & 15 \\
\hline & & $\begin{array}{l}\text { Kalimat yang digunakan mudah dipahami dan } \\
\text { dimengerti }\end{array}$ & 1 & 16 \\
\hline & & Jumlah & & 16 \\
\hline
\end{tabular}

Analisis data pada penelitian ini menggunakan teknik analisis data deskriptif kualitatif dan kuantitatif. Analisis deskriptif kualitatif bertujuan untuk mengolah data berupa masukan maupun saran dari review oleh ahli terhadap media video pembelajaran yang dikembangkan melalui pemberian kuesioner/angket. Hasil analisis kemudian digunakan untuk melakukan revisi media video pembelajaran. Analisis deskriptif kuantatif bertujuan untuk mendeskripsikan skor rata-rata dari media video pembelajaran yang dikembangkan. Skor yang telah didapatkan lalu di rata-ratakan guna mengetahui validitas media video pembelajaran dengan memakai rumus mean. 


\section{HASIL DAN PEMBAHASAN}

Hasil

Pengembangan video pembelajaran mengacu pada model pengembangan ADDIE yang tahapannya meliputi: Analisis (Analysis), Desain (Design), Pengembangan (Development), Implementasi (Implementation), dan Evaluasi (Evaluation). Produk yang dihasilkan divalidasi oleh dua dosen ahli materi, dua dosen ahli media, empat guru dan 23 respon siswa untuk menguji tingkat kepraktisan dan uji efektifitas oleh 23 siswa di SD Negeri 1 Nusasari. Adapun tahap-tahap dari model ADDIE dapat dipaparkan sebagai berikut. Pertama tahap analisis dilakukan analisis kurikulum, dan analisis kebutuhan. Analisis kurikulum bertujuan untuk mengetahui, kompetensi inti dan kompetensi dasar dari materi PPKn yang akan disusun dalam produk. Hasil yang didapatkan adalah KI dan KD, indikator capaian serta materi pokok. Analisis kurikulum dilakukan agar pengembangan produk tidak melenceng dari kompetensi inti dan komptensi dasar serta indikator yang ditetapkan. Hasil yang diperoleh dari analisis permasalahan pembelajaran PPKn di SD yaitu prestasi belajar siswa masih rendah. Hal ini ditunjukkan oleh informasi PISA 2018 yaitu skor sains siswa Indonesia menduduki peringkat ke70 dari 78 negara (OECD, 2019). Faktor-faktor penyebab kurang efektifnya pembelajaran di kelas, diperkuat dengan telah dilakukannya wawancara pada tanggal 30 melalui media sosial (Whatsapp) dengan beberapa guru yang melaksanakan pembelajaran PPKn di kelas VI SD Negeri 1 Nusasari khusunya dalam mengajar mata pelajaran PPKn tentang pengembangan perangkat pembelajaran, diperoleh informasi sebagai berikut. Dalam pelaksanaan pembelajaran guru masih tergantung materi pada buku siswa (tematik) dan belum menggunakan buku pendamping untuk memperluas dan memperdalam materi PPKn, dalam penggunaan media pembelajaran masih terbatas dengan media gambar saja, dalam menggunakan media pembelajaran, guru belum pernah menggunakan media kongkrit hanya tergantung pada media gambar yang disiapkan oleh sekolah dan gambar pada buku dimateri pelajaran. Selanjutnya pada analisis kurikulum didapat hasil ditetapkan bahwa penyusunan media video pembelajaran ini mengacu pada Kurikulum 2013 dengan ketentuan pemetaan KI dan KD mata pelajaran PPKn di kelas VI yaitu kompetensi dasar 3.1 sampai dengan kompetensi dasar 3.3. Hasil analisis kurikulum disajikan pada Tabel 4.

Tabel 4. Hasil Analisis Kurikulum

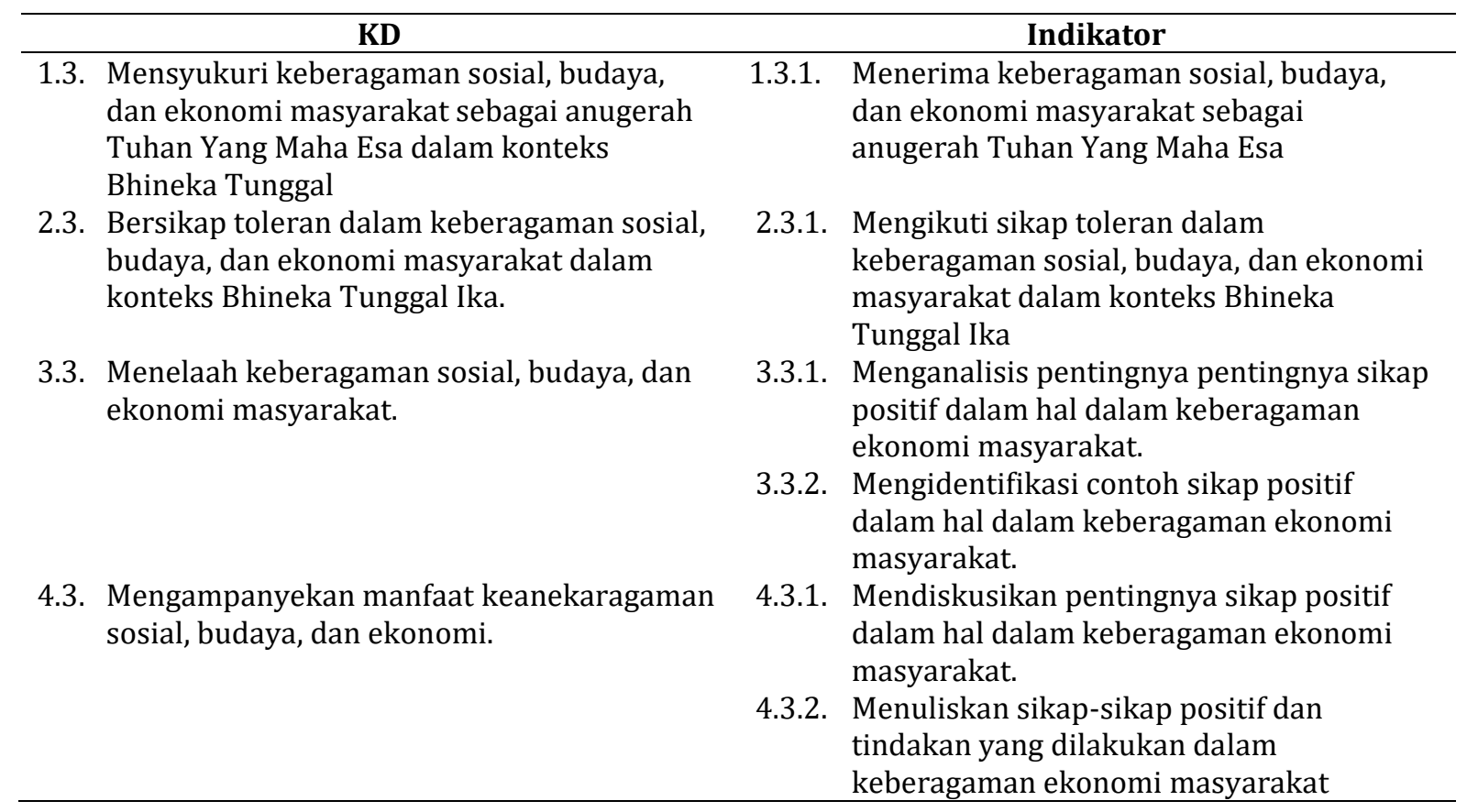

Kedua tahap desain, kegiatan pada tahap desain adalah pembuatan storyboard media video pembelajaran PPKn. Sebelum membuat produk, peneliti mengumpulkan refrensi gambar karakter dan alur cerita yang sesuai, dan mengumpulkan materi PPKn kelas VI. Selanjutnya setelah terkumpul dimulai pembuatan media video pembelajaran PPKn menggunakan aplikasi Powtoon. Storyboard menjadi desain dasar tampilan media video pembelajaran PPKn kelas VI. Pada tahap ini dilakukan pembuatan grand design yang berisi kerangka awal produk. Kegiatan selanjutnya pembuatan produk video pembelajaran. Produk yang telah disususn dijadikan acuan dalam pembuatan rubrik validasi ahli materi, ahli konstruk, validasi guru, dan uji keterbacaan. Hasil yang diperoleh dalam tahapan ini berupa produk video 
pembelajaran, rubrik validasi ahli dan uji kepraktisan dan uji kefektifan. Adapun gambar media video pembelajaran yang telah berhasil dikembangkan dapat dilihat pada Gambar 1.

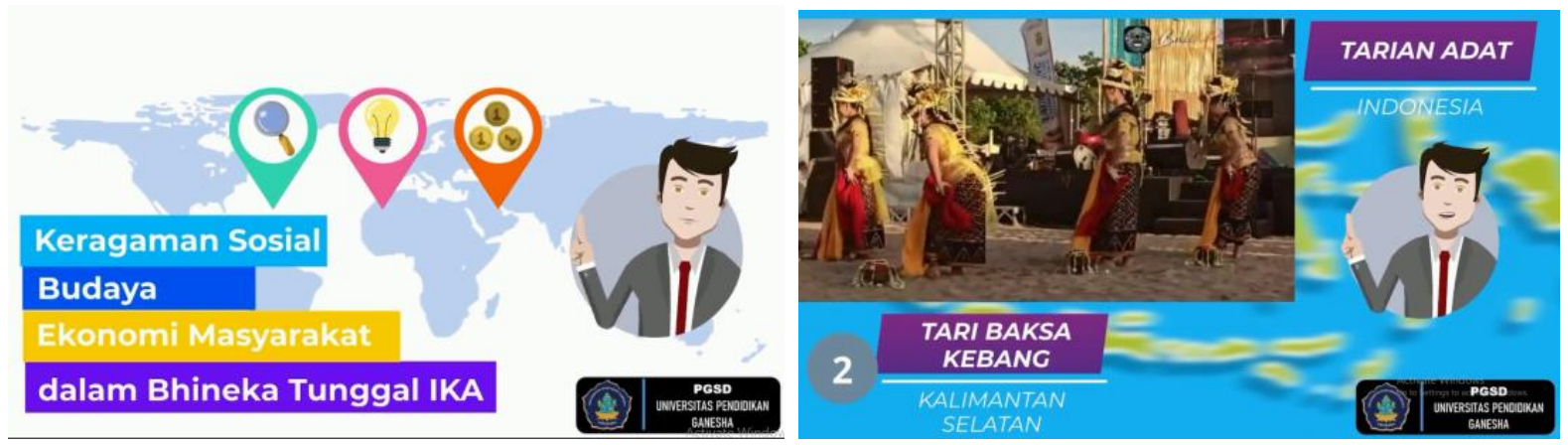

Gambar 1. Media Video Pembelajaran

Ketiga tahap pengembangan, hasil pengembangan video pembelajaran dilaksanakan pada tahap pengembangan (development). Kegiatan pengembangan video pembelajaran terdiri atas menyusun produk menjadi bentuk video dengan format $m p 4$, penilaian instrument, uji validasi produk video pembelajaran, uji kepraktisan, uji efektifitas dengan mengukur hasil belajar siswa pada ranah kognitif. Hasil uji validitas instrument dianalisis dengan analisis Gregory dengan hasil pada Tabel 5. Berdasarkan hasil pertimbangan dengan analisis keseluruhan uji validasi instrument memperoleh koefesien validitas 1,00 dengan kriteria sangat baik, sehingga disimpulkan bahwa instrument pengambilan data dinyatakan valid dan dapat digunakan sebagai instrumen yang digunakan ahli untuk memvalidasi media video pembelajaran. Uji kevalidan dilakukan kepada dua orang ahli. Hasil pertimbangan dengan analisis keseluruhan uji validasi video pembelajaran dari segi materi dan media memperoleh koefesien validitas 1,00 dengan kriteria sangat baik, sehingga disimpulkan bahwa video pembelajaran dinyatakan valid dan dapat digunakan untuk menguji tingkat kepraktisan, mengetahui respon siswa dan menguji tingkat efektifitas video pembelajaran.Uji kepraktisan dilakukan kepada guru PPKn sejumlah empat orang di SD Negeri 1 Nusasari dan kepada siswa kelas VI sejumlah 23 orang di SD Negeri 1 Nusasari. Hasil uji kepraktisan dianalisis dengan skor rata-rata sesuai kriteria kepraktisan yang telah ditentukan. Hasil analisis kepraktisan diperoleh bahwa video pembelajaran memiliki nilai kepraktisan rata-rata dengan kriteria sangat baik $(86,0)$. Hasil tersebut dapat disimpulkan bahwa video pembelajaran yang telah dikembangkan dinyatakan praktis tanpa revisi. Hasil uji kepraktisan kepada 23 orang siswa kelas VI SD 1 Nusasari dilakukan setelah siswa diberikan pengajaran dengan menggunakan video pembelajaran. Video pembelajaran memiliki nilai kepraktisan rata-rata dengan kriteria sangat baik $(92,4)$. Hasil tersebut dapat disimpulkan bahwa video pembelajaran yang telah dikembangkan dinyatakan praktis tanpa revisi.

Keempat tahap implementasi, hasil implementasi video pembelajaran dilaksanakan pada tahap implementasi (implementation). Kegiatan implementasi video pembelajaran dengan menerapkan pembelajaran kepada siswa pada materi Globalalisasi yang dilaksanakan sebanyak satu kali pertemuan pembelajaran dan pengambilan data pretest dan posttest. Pelaksanaan kegiatan implementasi dilakukan pada siswa kelas VI SD Negeri 1 Nusasari yang berjumlah 23 orang siswa. Implementasi mengikuti rancangan One Group Pretest Posttest Design. Pelaksanaan kegiatan berlangsung secara tatap muka dengan mematuhi protocol kesehatan. Proses pembelajaran dibantu dengan perangkat elektronik Laptop serta proyektor. Siswa diberikan pretest dengan instrumen tes untuk mengukur prestasi belajar sejumlah 10 butir soal. Siswa diberikan waktu selama 120 menit. Setelah siswa diberikan soal, siswa diberikan pembelajaran tatap muka dan menggunakan video pembelajaran. Proses pembelajaran telah disusun dalam rencana pelaksanaan pembelajaran (RPP). Setelah siswa diberikan pembelajaran, siswa kembalii diberikan tes yang sama yaitu instrumen tes untuk mengukur prestasi belajar sejumlah 10 butir soal. Siswa diberikan alokasi waktu menjawab selama 120 menit.

Kelima tahap evaluasi, pada tahap terakhir dari model pengembangan ADDIE adalah tahap penilaian (evaluate). Hasil dari tahap penilaian ini yaitu menilai kualitas proses dan hasil pembelajaran setelah video pembelajaran digunakan pada proses pembelajaran di kelas. Keefektivitasan video pembelajaran diukur dari ketercapaian hasil belajar siswa dengan menggunakan video pembelajaran yang telah dikembangkan. Data uji keefektivitasan dikumpulkan dengan memberikan tes untuk mengukur hasil belajar siswa berupa tes uraian sebanyak 10 butir soal kepada siswa pada awal pertemuan untuk data pretest dan akhir pertemuan untuk data posttest. Hasil analisis data pretest dan posttest siswa disajikan secara lengkap pada lampiran. Hasil belajar siswa dianalis dari hasil analisis rata-rata, standar deviasi dan $N$-gain score ternormalisasi. Nilai rata-rata hasil belajar siswa pada pretest memperoleh nilai sebesar 
50,00 dengan kualifikasi kurang, sedangkan nilai rata-rata hasil belajar pada posttest memperoleh nilai sebesar 76,09 dengan kualifikasi baik. Ditinjau dari sebaran data hasil belajar, diperoleh sebaran data hasil belajar saat posttest lebih baik dariada pretest, dilihat dari nilai standar deviasi yang lebih rendah saat pretest $(7,21)$ daripada nilai standar deviasi saat posttest $(7,35)$. Berdasarkan nilai yang diperoleh pada masing-masing pretest dan posttest, analisis dengan $\mathrm{N}$-gain score ternormalisasi diperoleh peningkatan yang sangat baik. Hasil <g> menunjukkan peningkatan hasil belajar sebesar 0,52 dengan kualifikasi sedang. Hasil analisis ini dapat disimpulkan bahwa video pembelajaran PPKn mampu meningkatkan hasil belajar siswa dengan efektif.

\section{Pembahasan}

Penelitian ini menghasilkan media video pembelajaran materi globalisasi pada mata pelajaran PPPKN. Video pembelajaran yang dikembangkan berbeda dengan video pembelajaran yang telah ada, karena video pembelajaran materi golbalisasi tersebut belum ada. Video ini dikembangkan dengan gambar, animasi bergerak, musik, efek dan transisi yang menarik serta didukung dengan teknologi. Media video ini dikembangkan berdasarkan hasil analisis kebutuhan guru di SD Negeri 1 Nusasari pada kelas VI sekolah dasar. Selain itu, video pembelajaran ini dibuat dengan semenarik mungkin, serta didukung dengan bantuan teknologi. Dengan dikembangkannya video pembelajaran ini diharapkan dapat membantu membelajarkan siswa dan menambah pengetahuan siswa khususnya pada topik globalisasi. Video pembelajaran yang dihasilkan dalam penelitian ini dinyatakan valid. Hal tersebut berdasarkan tahap pengembangan, validasi instrumen dan product yang berupa Video oleh guru dan dosen sebagai ahli. Pertama, validitas isi media dari video pembelajaran memperoleh kriteria validitas tinggi dan validitas responden memperoleh kategori sangat baik. penilaian ahli materi mendapat skor sebesar 1,00 dengan kriteria "validitas sangat baik". Hal tersebut dikarenakan tujuan pembelajaran disampaikan secara jelas dalam media video pembelajaran dan dari penyampaian materi pada media video pembelajaran dapat menarik minat belajar bagi siswa. Serta skor sebesar 1,00 dari hasil penilaian ahli media dengan kriteria "validitas sangat baik". Hal tersebut dikarenakan gambar/video yang ditampilkan dengan materi yang dibelajarkan sesuai serta kombinasi warna pada media video pembelajaran disusun dengan baik dan tata letak tulisan yang ditampilkan pada video pembelajaran sudah serasi. Didukung oleh hasil penilaian para responden pada video pembelajaran yang telah di analisis menggunakan rumus Mean mendapat skor sebesar 92,4. Hal tersebut dikarenakan penyajian materi pada media video pembelajaran membuat siswa menyimak dengan baik serta materi yang disampaikan dalam dia video pembelajaran penting untuk siswa. Jika skor penilaian para responden dikonversikan ke dalam konversi skala lima, maka rata-rata dari masing-masing skor masuk ke dalam kategori "Sangat Baik". Hal tersebut sejalan dengan penelitian yang menunjukkan bahwa, dengan diterapkannya media vide pembelajaran terdapat peningkatan nilai ratarata hasil evaluasi siswa (Arsyad \& Sulfemi, 2018; Muhson, 2010; Nahdi et al., 2018).

Kedua, hasil analisis yang diperoleh setelah dikonversikan, bahwa media video pembelajaran materi gelobalisasi layak digunakan untuk mendukung proses pembelajaran "Valid". Video pembelajaran materi gelobalisasi dapat dinyatakan valid oleh karena sudah sesuai dengan aspek-aspek yang termuat dalam video pembelajaran tersebut. Video pembelajaran materi gelobalisasi memiliki 5 aspek meliputi aspek pembelajaran, aspek materi, aspek kualitas media yang dikembangkan, aspek penggunaan bahasa, dan aspek tampilan media. Dilihat dari hasil analisis yang dilakukan keseluruhan aspek-aspek yang termuat dalam video pembelajaran. Sedangkan analisis validitas dari para responden dengan rumus Mean keseluruhan aspek-aspek tersebut berada dalam rentangan kategori baik-sangat baik. Hal tersebut sejalan dengan penelitian yang menunjukkan hasil validasi materi sebesar 3,53 dengan kategori valid, hasil validasi media menunjukkan hasil sebesar 3,28 dengan kategori valid, sehingga media audio visual yang dikembangkan layak untuk digunakan (Anjarsari et al., 2020). Penelitian yang menunjukkan bahwa media video sangat layak untuk dikembangkan (Karisma et al., 2019). Hal tersebut didukung oleh penelitian yang menyatakan media video selalu menampilkan gambar dan suara, dan media video pembelajaran dapat mengefisienkan waktu selama proses pembelajaran, serta membuat apa yang diterima oleh siswa menjadi lebih lama dan lebih baik tinggal dalam ingatan(Hernawati, 2018; Marhani \& Umar, 2017).

Ketiga, dari hasil analisis kurikulum yang telah dilaksanakan bahwa materi pembelajaran dalam video pembelajaran sudah sesuai dengan KD maupun SK. Sementara itu kualitas media video pembelajaran dan segi pengoperasiannya terbilang mudah. Hal itu dibuktikan dengan perancangan dan pengembangan video pembelajaran yang dilaksanakan dengan baik sehingga menciptakan hasil yang baik. Media video pembelajaran ini juga dapat menumbuhkan minat belajar siswa. Hal itu dibuktikan dari hasil data uji coba produk yang telah dilaksanakan bahwa video pembelajaran demonstrasi dengan media konkret dinyatakan "Valid" sehingga dapat membantu guru dalam melaksanakan pembelajaran (Kurniawan et al., 2018; Wisada et al., 2019). Dengan demikian pengembangan video materi gelobalisasi diharapkan mampu menambah wawasan dan pengetahuan siswa serta memberikan pemahaman yang 
lebih mendalam mengenai materi globalisasi. Penggunaan video pembelajaran materi gelobalisasi di kelas VI sekolah dasar cocok digunakan untuk meningkatkan hasil belajar siswa. Temuan ini diperkuat dengan temuan sebelumnya menyatakan video pembelajaran layak dan valid digunakan pada proses pembelajaran (Wulandari et al., 2020; Yuniarni et al., 2020). Penggunaan media pembelajaran melalui media gambar pada audio visual/video dapat meningkatkan hasil belajar siswa (Citra, 2017; Ponza, dkk. 2018). Media video dapat meningkatkan minat belajar siswa (Andriyani \& Suniasih, 2021; Dewi \& Handayani, 2021). Adapun kelebihan dari penelitian ini adalah dengan menerapkan model ADDIE secara keseluruhan. Pengembangan video yang dibuat belum pernah ada yang mengembangkan pada materi gelobalisasi. Video yang telah dikembangkan memiliki animasi serta Bahasa yang mudah dipahami oleh siswa. Dengan adanya penelitian ini peneliti-peneliti lain dapat menggunakan penelitian ini sebagai refresnsi untuk penelitian sejenisnya. Selain itu, diharapkan mampu mengembangkan penelitianpenelitian sejenis dengan menggunakan model atau pendekatan yang berbeda agar penelitian sejenis ini semakin banyak refrensi dan berguna untuk dunia Pendidikan. Implikasi penelitian ini yaitu dengan adanya video pembelajaran materi gelobalisasi di kelas VI sekolah dasar dapat membantu proses pembelajaran khususnya pada materi gelobalisai. Guru harus mampu membuat media pembelajaran yang memanfaatkan teknologi seperti video pembelajaran agar proses pembelajaran lebih bervariasi. Adapun saran yang dapat disampaikan adalah dengan adanya penelitian ini diharapkan menjadikan salah satu opsi dalam membatu pelaksanaan proses pembelajaran di sekolah dan diharpkan dengan adanya penelitian ini dapat dipergunakan sebagai referensi dalam melakukan penelitian yang relevan.

\section{SIMPULAN}

Media Video Pembelajaran Materi Globalisasi Pada Mata Pelajaran PPKn Siswa Kelas VI memiliki kriteria sangat valid, dilihat dari penilaian ahli materi dan ahli media. Dengan demikian video yang telah dikembangkan pada materi Globalisasi Pada Mata Pelajaran PPKn Siswa Kelas VI layak untuk digunakan dalam proses pembelajaran. hal tersebut dikarena media video yang dikembangkan pada materi gelobalilasi dapat membuat siswa antusias dalam mengikuti pembelajaran. Selain itu dengan adanya video tersebut siswa juga dapat belajar secara kongkrit dan akan menyebabkan meningkatnya proses pembelajaran serta hasil belajar siswa.

\section{DAFTAR PUSTAKA}

Aditya, I. P. E., Asri, I. G. A. A. S., \& Ardana, I. K. (2019). Pengaruh Model Pembelajaran Snowball Throwing Berbantuan Media Video Terhadap Kompetensi Pengetahuan PPKn Siswa Kelas V SD Gugus III Kecamatan Kuta Utara Tahun Ajaran 2018/2019. Media Komunikasi FPIPS, 17(1), 44-53. https://doi.org/10.23887/mkfis.v17i1.22217.

Ananda, R. (2017). Penggunaan Media Audio Visual untuk Meningkatkan Hasil Belajar Pendidikan Kewarganegaraan Siswa Kelas IV SD Negeri 016 Bangkinang Kota. Jurnal Basicedu, 1(1), 21-30. https://doi.org/10.31004/basicedu.v1i1.149.

Andriyani, N. L., \& Suniasih, N. W. (2021). Development Of Learning Videos Based On Problem-Solving Characteristics Of Animals And Their Habitats Contain in Science Subjects On 6th-Grade. Journal of Education, 5(1), 37-47. https://doi.org/10.23887/jet.v5i1.32314.

Anjarsari, E., Farisdianto, D. D., \& Asadullah, A. W. (2020). Pengembangan Media Audiovisual Powtoon pada Pembelajaran Matematika untuk Siswa Sekolah Dasar. Jurnal Matematika Dan Pendidikan Matematika, 5(2), 40-50. https://doi.org/10.26594/jmpm.v5i2.2084.

Aprilia, L. A., Slameto, S., \& Radia, E. H. (2018). Meningkatkan Hasil Belajar Ppkn Melalui Model Pembelajaran Numbered Heads Together (NHT) Berbasis Kurikulum 2013. WACANA AKADEMIKA: Majalah Ilmiah Kependidikan, 2(1), 85. https://doi.org/10.30738/wa.v2i1.2530.

Arsyad, A., \& Sulfemi, W. B. (2018). Metode Role Playing Berbantu Media Audio Visual Pendidikan dalam Meningkatkan Belajar IPS. Jurnal PIPSI (Jurnal Pendidikan IPS Indonesia), 3(2), 41. https://doi.org/10.26737/jpipsi.v3i2.1012.

Asmedy, A. (2021). Pengaruh Model Pembelajaran Kooperatif Tipe STAD Terhadap Hasil Belajar Siswa Sekolah Dasar. Ainara Journal (Jurnal Penelitian Dan PKM Bidang Ilmu Pendidikan), 2(2), 108-113. https://doi.org/10.54371/ainj.v2i2.41.

Ayala, A. P. (2021). A learning design cooperative framework to instill 21st century education. Telematics and Informatics, 62. https://doi.org/10.1016/j.tele.2021.101632.

Boso, C. M., van der Merwe, A. S., \& Gross, J. (2021). Students' and Educators' Experiences with Instructional Activities Towards Critical Thinking Skills Acquisition in a Nursing School. International Journal of Africa Nursing Sciences, 14, 100293. 
https://doi.org/10.1016/j.ijans.2021.100293.

Dewi, F. F., \& Handayani, S. L. (2021). Pengembangan Media Pembelajaran Video Animasi En-Alter Sources Berbasis Aplikasi Powtoon Materi Sumber Energi Alternatif Sekolah Dasar. Jurnal Basicedu, 5(4), 2530-2540. https://doi.org/10.31004/basicedu.v5i4.1229.

Diana Sari, N. L. S., Sudana, D. N., \& Parmiti, D. P. (2019). Pengaruh VCT Berbantuan Media Sederhana Terhadap Hasil Belajar PKN. Journal of Education Technology, 3(2), 49. https://doi.org/10.23887/jet.v3i2.21701.

Farida Hasan Rahmaibu, F. A. F. D. P. (2017). Pengembangan Media Pembelajaran Menggunakan Adobe Flash Untuk Meningkatkan Hasil Belajar PKn. Jurnal Kreatif: Jurnal Kependidikan Dasar, 7(1).

Fatmawati, Y., \& Rizal, A. R. (2020). Peranan Model Pembelajaran Value Clarification Technique Berbantuan Media Audio Visual untuk Meningkatkan Hasil Belajar IPS. JISIP (Jurnal Ilmu Sosial Dan Pendidikan), 4(4), 53-68. https://doi.org/10.36312/jisip.v4i4.1186.

Fitria, A. (2018). Penggunaan Media Audio Visual dalam Pembelajaran Anak Usia Dini. Cakrawala Dini: Jurnal Pendidikan Anak Usia Dini, 5(2). https://doi.org/10.17509/cd.v5i2.10498.

Gusnawan, I. M. V., \& Renda, N. T. (2017). Pengaruh Model Pembelajaran Resolusi Konflik Berbantuan Media Video Clip Terhadap Hasil Belajar PKN. MIMBAR PGSD, 5(3). https://doi.org/10.23887/jjpgsd.v5i3.12433.

Hasanah, A., Indrawadi, J., \& Montessori, M. (2020). Pembelajaran Pendidikan Pancasila dan Kewarganegaraan (PPKn) di Daerah Tertinggal. Jurnal of Moral and Civic Education, 4(2), 69 - 77. https://doi.org/10.24036/8851412412020223.

Hastuti, H. W., Baedowi, S., \& Mushafanah, Q. (2019). Keefektifan Model Pembelajaran Numbered Heads Together Berbantu Media Panelpa (Papan Flanel IPA) Terhadap Hasil Belajar. International Journal of Elementary Education, $3(2), \quad$ 108-115. https://doi.org/http://dx.doi.org/10.23887/ijee.v3i2.18513.

Hernawati, E. (2018). Meningkatkan Hasil Belajar Fisika Melalui Penggunaan Metode Demonstrasi dan Media Audiovisual pada Siswa Kelas X MAN 4 Jakarta. Andragogi: Jurnal Diklat Teknis Pendidikan Dan Keagamaan, 6(2), 118-131. https://doi.org/10.36052/andragogi.v6i2.60.

Hikmah, U. N., \& Ahmadi, F. (2019). Pengembangan Media Video Pembelajaran Untuk Meningkatkan Hasil Belajar PKn Siswa Kelas. Jurnal Kreatif: Jurnal Kependidikan Dasar, 9(2), 135-140. https://doi.org/10.15294/kreatif.v9i2.25408.

Hong, J.-C., Lee, Y.-F., \& Ye, J.-H. (2021). Procrastination predicts online self-regulated learning and online learning ineffectiveness during the coronavirus lockdown. Personality and Individual Differences, 1-8. https://doi.org/https://doi.org/10.1016/j.paid.2021.110673.

Jr., L. D. L., Tiangcoa, C. E., Sumalinog, D. A. G., Sabarillo, N. S., \& Mark, J. (2021). An effective blended online teaching and learning strategy during the Covid-19 pandemic. Education for Chemical Engineers, 35, 116-131. https://doi.org/https://doi.org/10.1016/j.ece.2021.01.012.

Karisma, R., Mudzanatun, \& Arisyanto, P. (2019). Pengembangan Media Audio Visual untuk Mendukung Pembelajaran Tematik Tema \& Subtema 2. Jurnal Penelitian Dan Pengembangan Pendidikan. https://doi.org/http://dx.doi.org/10.23887/jppp.v3i3.19255.

Khaulani, F., Noviana, E., \& Witri, G. (2019). Penerapan Metode Brainstorming Dengan Bantuan Media Gambar Grafis Untuk Meningkatkan Hasil Belajar Pkn Siswa Kelas V SD Negeri 009 Pulau Kecamatan Bangkinang Kabupaten Kampar. JURNAL PAJAR (Pendidikan Dan Pengajaran), 3(1), 18. https://doi.org/10.33578/pjr.v3i1.6305.

Kurniawan, D., Kuswandi, D., \& Husna, A. (2018). Pengembangan Media Video Pembelajaran Pada Mata Pelajaran Ipa Tentang Sifat Dan Perubahan Wujud Benda Kelas Iv Sdn Merjosari 5 Malang. JINOTEP (Jurnal Inovasi Dan Teknologi Pembelajaran) Kajian Dan Riset Dalam Teknologi Pembelajaran, 4(2), 119-125. https://doi.org/10.17977/um031v4i22018p119.

Kurniyawati, S. U., \& Nugraheni, A. S. (2021). Pengembangan Media Pembelajaran Interaktif Berbasis Gawai Pada Pembelajaran PPKn Kelas 3 SD/MI Di Masa Pandemi Covid-19. ELSE (Elementary School Education Journal): Jurnal Pendidikan Dan Pembelajaran Sekolah Dasar, 5(2), 159-171. https://doi.org/10.30651/else.v5i2.7099.

Kwangmuang, P., Jarutkamolpong, S., Sangboonraung, W., \& Daungtod, S. (2021). The development of learning innovation to enhance higher order thinking skills for students in Thailand junior high schools. Heliyon, 7(6). https://doi.org/10.1016/j.heliyon.2021.e07309.

Lavi, R., Tal, M., \& Dori, Y. J. (2021). Perceptions of STEM alumni and students on developing 21st century skills through methods of teaching and learning. Studies in Educational Evaluation, 70, 1-11. https://doi.org/https://doi.org/10.1016/j.stueduc.2021.101002.

Layona, R., Yulianto, B., \& Tunardi, Y. (2017). Authoring Tool for Interactive Video Content for Learning Programming.

Procedia

Computer

Science,

116 ,

37-44. 
https://doi.org/10.1016/j.procs.2017.10.006.

Maharni. (2016). Pengembangan Media Video Untuk Perolehan Belajar Konsep Norma-. Kehidupan, Norma Pelajaran, Pada Kewarganegaraan, Pedidikan, 1(2), 41-51.

Mediatati, N., \& Suryaningsih, I. (2017). Penggunaan model pembelajaran Course Review Horay dengan media flipchart sebagai upaya meningkatkan hasil belajar PKn. Jurnal Ilmiah Sekolah Dasar, 1(2), 113-121. https://doi.org/10.23887/jisd.v1i2.10146.

Mishra, L., Gupta, T., \& Shree, A. (2020). Online teaching-learning in higher education during lockdown period of COVID-19 pandemic. International Journal of Educational Research Open, June, 100012. https://doi.org/10.1016/j.ijedro.2020.100012.

Miswandi, M. (2018). Peningkatan Hasil Belajar PKN SD melalui Stategi Crossword Puzzle. Jurnal Pendidikan : Riset Dan Konseptual, 2(3), 300. https://doi.org/10.28926/riset_konseptual.v2i3.66.

Muhson, A. (2010). Pengembangan Media Pembelajaran Berbasis Teknologi Informasi. Jurnal Pendidikan Akuntansi Indonesia, 8(2). https://doi.org/10.21831/jpai.v8i2.949.

Murni, H. (2018). Upaya Meningkatkan Hasil Belajar Model Pembelajaran PKN Melalui Model Pembelajaran Kooperatif Tipe Think Pair Share. Wahana Didaktika: Jurnal Ilmu Kependidikan, 16(3), 284. https://doi.org/10.31851/wahanadidaktika.v16i3.2105.

Naharir, R. A., Dantes, N., \& Kusmariyatni, N. (2019). Pengaruh Model Pembelajaran Course Review Horay Berbantuan Media Video Pembelajaran Terhadap Hasil Belajar Matematika Siswa Kelas V Semester II Sd Gugus VI Kecamatan Sukasada. Mimbar PGSD Undiksha, 7(1). https://doi.org/10.23887/jjpgsd.v7i1.16975.

Purbasari, F., Rusnaini, R., \& Winarno, W. (2016). Pengaruh Model Pembelajaran Value Clarifica Tion Technique (VCT) Tipe Analisis Nilai Berbantuan Media Video Pembelajaran Terhadap Penguasaan Kompetensi Dasar. Paedagogia. Paedagogia, $19(2), \quad 156-169$. https://doi.org/10.20961/paedagogia.v19i2.36083.

Ramadhani, S. P. (2017). Pengaruh Pendekatan Cooperative Learning Tipe (TPS) Think, Pair, and Share Terhadap Hasil Belajar PKn di Sekolah Dasar. Premiere Educandum : Jurnal Pendidikan Dasar Dan Pembelajaran, 7(02), 124. https://doi.org/10.25273/pe.v7i2.1653.

Ridha, M., Firman, \& Desyandri. (2021). Efektifitas Penggunaan Media Video pada Pembelajaran Tematik Terpadu di Sekolah Dasar Saat Pandemi Covid-19. Jurnal Pendidikan Tambusai, 5(1), 154-162.

Salim Nahdi, D., Yonanda, D. A., \& Agustin, N. F. (2018). Upaya Meningkatkan Pemahaman Konsep Siswa Melalui Penerapan Metode Demonstrasi pada Mata Pelajaran IPA. Jurnal Cakrawala Pendas, 4(2), 9. https://doi.org/10.31949/jcp.v4i2.1050.

Scherer, R., Howard, S. K., Tondeur, J., \& Siddiq, F. (2021). Profiling teachers' readiness for online teaching and learning in higher education: Who's ready? Computers in Human Behavior, 118, 106675. https://doi.org/10.1016/j.chb.2020.106675.

Siswinarti, P. R. (2019). Pengaruh Model Pembelajaran Value Clarification Technique Bermediakan Video Terhadap Hasil Belajar Pkn. Jurnal Ilmiah Pendidikan Profesi Guru, 2(1), 41-49. https://doi.org/10.23887/jippg.v2i1.18084.

Siswinarti, Pt. Ratih. (2019). Pengaruh Model Pembelajaran Value Clarification Technique Bermediakan Video Terhadap Hasil Belajar Pkn. Jurnal Ilmiah Pendidikan Profesi Guru, 2(1), 41-49. https: //doi.org/10.23887/jippg.v2i1.18084.

Sri Kartika Dewi, N. W., Parmiti, D. P., \& Ngurah Japa, I. G. (2019). Pengaruh Model Pembelajaran Probing Prompting Berbantuan Media Video Terhadap Hasil Belajar IPA. Indonesian Journal Of Educational Research and Review, 2(2), 229. https://doi.org/10.23887/ijerr.v2i2.17631.

Suandewi, N. P., Dibia, I. K., \& Dharsana, I. K. (2017). Pengaruh Model Pembelajaran Nos Untuk Meningkatkan Hasil Belajar IPA Melalui Lesson Study Siswa Kelas V. Mimbar PGSD, 5(3), 1-11. https://doi.org/10.23887/jjpgsd.v5i3.12061.

Susilo, S. V., \& Ramdiati, T. (2019). Penerapan Model Multiliterasi Untuk Meningkatkan Keterampilan Menulis Karangan Persuasi Pada Mata Pelajaran Bahasa Indonesia Di Sekolah Dasar. Jurnal Cakrawala Pendas, 5(1). https://doi.org/10.31949/jcp.v5i1.1199.

Wisada, P. D., Sudarma, I. K., \& Yuda S, A. I. W. I. (2019). Pengembangan Media Video Pembelajaran Berorientasi Pendidikan Karakter. Journal of Education Technology, 3(3), 140. https: //doi.org/10.23887/jet.v3i3.21735.

Wulandari, Y., Ruhiat, Y., \& Nulhakim, L. (2020). Pengembangan Media Video Berbasis Powtoon pada Mata Pelajaran IPA di Kelas V. Jurnal Pendidikan Sains Indonesia, 8(2), 269-279. https://doi.org/10.24815/jpsi.v8i2.16835.

Yuniarni, Sari, \& Atiq. (2020). Pengembangan Multimedia Interaktif Video Senam Animasi Berbasis Budaya Khas Kalimantan Barat. Jurnal Obsesi: Jurnal Pendidikan Anak Usia Dini, 4(1). https://doi.org/10.31004/obsesi.v4i1.331. 